\title{
RRAGC wt Allele
}

National Cancer Institute

\section{Source}

National Cancer Institute. RRAGC wt Allele. NCI Thesaurus. Code C142216.

Human RRAGC wild-type allele is located in the vicinity of 1 p34.3 and is approximately 22 $\mathrm{kb}$ in length. This allele, which encodes Ras-related GT P-binding protein C, plays a role in regulating the localization of the mammalian target of rapamycin complex 1 (mTORC1). 